\title{
ANALISIS FUNGSI INTERMEDIASI BANK SYARIAH DI INDONESIA: STUDI KASUS DARI TAHUN 2003 SAMPAI TAHUN 2005
}

\author{
Sri Kusreni \\ Staff Pengajar Fakultas Ekonomi Universitas Airlangga
}

\begin{abstract}
ABSTRAK. Bank Syariah yang berfungsi sebagai intermediasi, menunjukkan peranan yang makin meningkat sesuai dengan kebijakan pemerintah Indonesia. Hal ini ditunjukkan dari data yang dikeluarkan oleh Bank Indonesia mulai tahun 2003 sampai dengan 2005. Untuk memperoleh hasil, digunakan Ordinary Least Square (OLS ) dimana FDR sebagai variabel tidak bebas dan variabel bebasnya adalah Return On Asset (ROA), Sertifikat Wadiah Bank Indonesia (SWBI), serta Industrial Production Index (IPI) Non Performing Finance (NPF). Analisis fungsi intermediasi bank Syariah yang diwakili oleh variabel FDR menghasilkan hubungan yang positif dengan ROA. Hasil estimasi menunjukkan bahwa untuk variabel FDR hanya variabel ROA yang menunjukkan hasil yang bertentangan dengan performance dari bank konvensional.
\end{abstract}

Kata kunci: Ordinary Least Square (OLS), Return on Assets (ROA), Industrial Production Index (IPI), Certificate of Bank Indonesia Wadiah (SWBI), Non-Performing Finance (NPF)

\section{ANALYSIS INTERMEDIARY FUNCTION SHARIA BANKS IN INDONESIA: A CASE STUDY FROM YEAR 2003 TO YEAR 2005}

\begin{abstract}
As financing intermediation function, the role of Sharia banking in Indonesia tended to increase along with Indonesian Government policies. It can be viewed through the data indicators released by Bank of Indonesia, from 2003 to 2005. To achieve the objective of Ordinary least square (OLS) we used FDR (Financing to Deposit Ratio) as Dependent variable, while independent variables are Return on asset (ROA), Industrial Production Index (IPI), Sertifikat Wadiah Bank Indonesia (SWBI), Non performing finance (NPF). Output of the analysis indicated that intermediation function of Sharia banking that represented by FDR is only impacted positively by ROA. The estimation shows that in FDR variable only ROA variable have act upon with conventional bank performance.
\end{abstract}

Keywords: Ordinary Least Square (OLS), Return on Asset (ROA), Industrial Production Index (IPI), Sertifikat Wadiah Bank Indonesia (SWBI), NonPerforming Finance (NPF). 


\section{PENDAHULUAN}

Sebagai agent of economic development, lembaga keuangan khususnya perbankan menempati posisi strategis dalam menjembatani kebutuhan modal kerja dan investasi sektor riil dengan pemilik dana. Hal ini disebabkan posisi perbankan dalam sistem keuangan timbul karena adanya mismatch antara pendapatan dan pengeluaran baik pada individu maupun perusahaan, kemudian timbul istilah unit surplus dan unit defisit (Hubbard, 2002). Sehingga fungsi utama sektor perbankan dalam infrastruktur kebijakan makro ekonomi diarahkan agar dana dapat dengan efektif dan efisien meningkatkan nilai tambah terhadap perekonomian. Agar perbankan mampu berperan, maka diperlukan suatu sistem perbankan yang sehat, tangguh dan adil.

Pada masa keterbukaan kompetisi bisnis jasa keuangan, termasuk dalam perbankan syariah, fungsi strategis tersebut justru ditangkap secara baik oleh perbankan syariah untuk mengembangkan kinerjanya dalam melayani masyarakat. Ternyata, pada kenyataan yang ada, pemerintah mendukung perkembanganya dengan mengeluarkan produk UU No. 7 Tahun 1992 tentang Perbankan yang direvisi menjadi UU No. 10 Tahun 1998 dan UU No. 23 Tahun 1999 tentang Bank Indonesia yang kemudian direvisi UU No. 3 Tahun 2004. Pada masa permulaan dan setelah penerbitan regulasi pemerintah, ternyata kinerja perbankan syariah mampu berkembang dengan pesat. Hal ini menggambarkan bahwa fenomena bank syariah bukan lagi sekedar sebuah wacana atau eksperimen belaka melainkan sudah tumbuh menjadi industri yang relatif subur dan menguntungkan.

Peningkatan kinerja perbankan syariah dalam melayani ummat memang perlu diberikan sebuah apresiasi tersendiri, namun juga harus dilihat dan diteliti seberapa jauh hal ini bekerja dan bagaimana penjelasan yang benar tentang kondisi ini. Salah satu analisis yang bisa dilakukan adalah melihat berbagi indikator yang paling relevan. Karena perkembang kinerja yang bagus akan diikuti oleh perkembangan berbagai indikator, dalam hal ini keuangan perbankan syariah. Dalam paper ini ada 5 indikator yang digunakan untuk mengukur serta mengevaluasi pertumbuhan perbankan syariah, diantaranya adalah FDR (Financing to Deposit ratio), ROA (Retun on Asset), NPF (Non Performing Finance), Wadi'ah Sertificate Bonus dan IPI (Industrial Production Index).

Rangkuman data indikator kinerja perbankan syariah yang disampaikan oleh BI menunjukkan bahwa telah terjadi pertumbuhan yang signifikan pada semester pertama tahun 2004, namun mengalami perlambatan pertumbuhan di semester pertama tahun 2005. Apabila dilihat dari kredit atau pembiayaan bermasalah (NPL/NPF), maka NPL/NPF perbankan syariah yang pada semester pertama 2005 mencapai 4,15\% masih dibawah NPL bank konvensional yang mencapai 7,6 \%. Sedangkan dalam hal rasio pembiayaan (FDR), pada semester pertama 2005 perbankan syariah mencatat tingkat FDR $108.49 \%$. Secara garis besar perkembangan Industri perbankan syariah bisa dinilai baik. Indikator ini berdasarkan pertumbuhan asset $84,09 \%$, pembiayaan yang disalurkan $77,79 \%$, 
dan dana pihak ketiga (DPK) perbankan syariah $87,08 \%$ sampai dengan semester pertama tahun 2005.

Sedangkan, satu variabel indikator lagi dikeluarkan oleh BPS yaitu Indeks Produksi Industri (IPI) menggambarkan keadaan industri sedang dan besar sebagai salah satu motor penggerak perekonomian dan digunakan sebagai indikator sektor riil yang dalam perkembangannya membutuhkan pembiayaan dari perbankan

Dengan melihat perkembangan perbankan syariah di Indonesia dan mengaitkan pada berbagai indikator data kelima variabel tersebut, perlu ditelaah kinerja intermediasi perbankan syariah. Sehubungan itu, paper ini menyajikan hasil penelitian mengenai analisis fungsi intermediasi yang telah disalurkan perbankan syariah di Indonesia melalui pendekatan variabel Financing to Deposit Ratio (rasio antara dana pihak ketiga dan pembiayaan yang disalurkan oleh perbankan syariah).

\section{METODE PENELITIAN}

Pendekatan penelitian yang digunakan adalah pendekatan kuantitatif deskriptif. Artinya penelitian ini merupakan gabungan terhadap variabel ekonomi yang lain serta penjelasan-penjelasan dari asumsi ilmu ekonomi (Muhammad, 2005). Sebagai usaha dalam mendapatkan suatu kesimpulan atau mengetahui korelasi antar variabel menggunakan analisis regresi berganda secara time series dengan periode penelitian 2003 - 2005. Metode yang digunakan dalam penelitian ini adalah metode Ordinary Least Square (OLS), hal ini dimaksudkan untuk mengetahui pengaruh dari variable-variaebl bebas terhadap variable tergantung.

Persamaan model dalam penelitian ini digunakan model persamaaan regresi yang akan diestimasi dengan menggunakan OLS (Ordinary Least Square). Adapun model regresi tersebut diadopsi dari model regresi penelitian Muliaman D Hadad dkk. (2004) kemudian dimodifikasi dan disesuaikan :

$$
F D R_{i, t}=\text { const }+\beta_{1} R O A+\beta_{2} N P F+\beta_{3} S W B I+\beta_{4} I P I+\varepsilon_{i, t}
$$

Keterangan :

$\begin{array}{ll}F D R & : \text { Rasio pembiayaan (Financing to Deposit Ratio) } \\ R O A & \text { : Rasio laba (Return on Asset) } \\ \text { NPF } & \text { : Rasio Pembiayaan bermasalah/macet (Non Performing Finance) } \\ \text { SWBI } & \text { : Bonus Sertifikat Wadi'ah Bank Indonesia bulanan } \\ I P I & \text { : Indeks Produksi Industri (Industrial Production Index) } \\ \beta_{1,} \beta_{2,} \beta_{3,} \beta_{4} & \text { : Koefisien regresi } \\ \varepsilon & \text { : Error term } \\ \mathrm{t} & \text { : Indikasi data runtun waktu (time series) }\end{array}$


Model regresi linier berganda (Ordinary Least Square) melihat hubungan antara dua bagian kelompok variabel. Salah satu variabel menjadi variabel independen dan yang lain menjadi variabel dependen (Gujarati, 2003). Sehingga untuk melihat hubungan antara variabel independen (ROA, NPF, SWBI, IPI) dengan varibel dependen $(F D R)$, dalam penelitian ini dapat juga digunakan teknik analisis Ordinary Least Square (OLS). Secara berurutan, teknis analisis penelitian ini akan dijelaskan pada sub bagian di bawah ini :

\section{Pengujian Akar-akar Unit (Unit Root Test)}

Pengujian akar-akar unit untuk semua variabel yang digunakan dalam analisis runtut waktu perlu dilakukan untuk memenuhi kesahihan analisis Ordinary Least Square (OLS). Ini berarti bahwa data yang dipergunakan harus bersifat stasioner, atau dengan kata lain perilaku data yang stasioner memiliki varians yang tidak terlalu besar dan mempunyai kecenderungan untuk mendekati nilai rata-ratanya (Enders,1995).

Uji ini menjadi penting untuk dilakukan karena metode regresi klasik (OLS) didesain untuk menangani hubungan antar variabel yang stasioner dan tidak seharusnya diaplikasikan pada data time series yang non-stasioner (Enders,1995). Ketika data time series yang non-stasioner digunakan dalam suatu model regresi maka akan timbul masalah yang disebut spurious regression, yaitu kondisi dimana model regresi yang langsung dan "seakan-akan" menunjukkan hubungan kuat antar variabel-variabelnya. Hal tersebut tampak pada nilai koefisien regresi yang sangat signifikan dan nilai dari koefisien determinasi $\left(R^{2}\right)$ dari model yang sangat besar, meskipun sebenarnya tidak ada hubungan apapun antar variabel-variabel tersebut.

Pengujian stasioneritas data yang dilakukan terhadap seluruh variabel dalam model penelitian, didasarkan pada Augmented Dickey Fuller Test, yang perhitungannya menggunakan bantuan software E-Views 4.1.

\section{Pengujian Statistik Koefisien Determinasi $\left(R^{2}\right)$}

Angka yang menunjukkan besarnya kemampuan variasi dari variabel bebas yang dapat diterangkan oleh variabel tak bebas. Besarnya koefisien determinasi berkisar antara nol sampai dengan satu, dimana semakin mendekati satu maka semakin dekat hubungan antara variabel bebas dengan variabel tak bebas.

\section{Uji $t$ - Statistik}

Pengujian t-statistik digunakan untuk menguji pengaruh parsial dari variabel bebas terhadap variabel tidak bebasnya. Pengujian ini dilakukan dengan hipotesis:

$\mathrm{H}_{0}: \beta=0$ (Variabel bebas tidak mempengaruhi variabel tidak bebasnya)

$\mathrm{H}_{1}: \beta \neq 0$ (Variabel bebas mempengaruhi variabel tidak bebasnya) 
Dengan menguji dua arah dalam tingkat signifikansi $=a$, dan derajat kebebasan (Degree of Freedom) $\mathrm{df}=\mathrm{n}-\mathrm{k}$, dimana $\mathrm{n}=$ jumlah observasi dan $\mathrm{k}=$ jumlah parameter termasuk konstanta. Maka hasil pengujian akan menunjukan :

$\mathrm{H}_{0}$ diterima bila | t-stat $\mid<\mathrm{t}$ - tabel

$\mathrm{H}_{0}$ ditolak bila |t-stat $\mid>\mathrm{t}$-tabel

\section{Uji F- Statistik}

Pengujian F-statistik digunakan untuk menguji signifikansi dari semua variabel bebasnya sebagai satu kesatuan atau mengukur pengaruh variabel bebas secara bersama-sama, Hipotesa yang digunakan adalah :

$\mathrm{H}_{0}$ : Semua variabel bebas secara bersama-sama tidak berpengaruh terhadap variabel tidak bebasnya

$\mathrm{H}_{1}$ : $\quad$ Setidak-tidaknya ada satu variabel bebas yang mempengaruhi variabel tidak bebasnya

Hasil Pengujian adalah :

- Apabila nilai $\mathrm{F}$ hitung $>\mathrm{F}$ tabel, berarti $\mathrm{H}_{0}$ ditolak, sehingga variabel bebasnya secara bersama-sama berpengaruh terhadap variabel tidak bebasnya

- Apabila $\mathrm{F}$ hitung $\leq \mathrm{F}$ tabel , berarti $\mathrm{H}_{0}$ diterima, sehingga variabel bebasnya secara bersama-sama tidak berpengaruh terhadap variabel tidak bebasnya

\section{Pengujian Masalah Asumsi Klasik Masalah Multikolinieritas}

Masalah mulitikolinearitas adalah situasi dimana adanya korelasi antara variabel bebas dengan variabel bebas lainnya. Dengan kata lain, dapat dikatakan bahwa sebuah model persamaan dinyatakan terdapat gangguan multikolinier apabila $\mathrm{R}^{2}$-nya tinggi namun hanya sedikit atau bahkan tidak ada variabel bebasnya yang signifikan pada pengujian t-statistik. Salah satu cara untuk mengetahui ada tidaknya masalah multikolinear yaitu dengan melihat matriks korelasi antara variabel bebas (variable independent).

\section{Masalah Heteroskedastisitas}

Heteroskedastisitas terjadi jika gangguan muncul dalam fungsi regresi yang mempunyai varian yang tidak sama, sehingga penaksir OLS tidak efisien baik dalam sampel kecil maupun sampel besar. Untuk mendeteksi ada atau tidaknya masalah Heteroskedastisitas adalah dengan menggunakan White Test. Kriteria pengujiannya adalah membandingkan nilai $(n-1) R^{2}$ diperbandingkan dengan $X^{2}$ $(0,05)$. Dimana $X^{2}(0,05)$ adalah nilai kritis Chi Square yang ada dalam tabel statistik Chi Square. Jika $(n-1) R^{2}$ lebih besar dari $X^{2}$, maka terdapat masalah Heteroskedastisitas, dan jika sebaliknya maka tidak terjadi masalah Heteroskedastisitas. 


\section{Masalah Autokorelasi}

Pengujian ini digunakan untuk mendeteksi adanya masalah autokorelasi (serial korelasi) dalam suatu model regresi linier. Autokorelasi adalah korelasi antara anggota serangkaian observasi yang diurutkan menurut waktu (seperti dalam data deretan waktu) atau ruang (seperti dalam data cross sectional). Adanya masalah autokolerasi ini akan menghasilkan hasil estimasi koefisien yang konsisten dan tidak bias tetapi dengan varian yang besar, atau dengan perkataan lain hasil penafsiran tidak efisien.

Untuk model OLS, Autokorelasi dengan melakukan percobaan DW tidak bisa digunakan untuk menguji ada tidaknya autokorelasi, karena DW statistik secara asimtotik akan biasa mendekati nilai 2 (Sritua Arief, 1993). Oleh karena alasan tersebut maka digunakan langrange Multiplier Test, yakni berupa regresi atas semua variabel bebas dalam persamaan regresi OLS tersebut dan variabel lag $\mathrm{t}$ dari nilai residual regresi OLS.

Dari model tersebut akan didapat nilai $\mathrm{R}^{2}$, kemudian nilai ini dimasukkan dalam rumus sebagai berikut : $(n-1) R^{2}$, dimana $n$ adalah jumlah observasi, kemudian dilakukan pengujian dengan hipotesa sebagai berikut :

$\mathrm{H}_{0}: \rho=0$ berarti tidak ada masalah autokorelasi

$\mathrm{H}_{1}: \rho \neq 0$ berarti ada masalah autokorelasi

Selanjutnya nilai $(n-1) R^{2}$ diperbandingkan dengan $X^{2}(0,05)$. Dimana $X^{2}(0,05)$ adalah nilai kritis Chi Square yang ada dalam tabel statistik Chi Square. Jika (n$1) \mathrm{R}^{2}$ lebih besar dari $\mathrm{X}^{2}$, maka terdapat masalah autokorelasi, dan jika sebaliknya maka tidak terjadi masalah autokorelasi.

\section{HASIL DAN PEMBAHASAN}

Pengujian Akar-akar Unit (Unit Root Test)

Pengujian stasioneritas data dilakukan terhadap seluruh variabel dalam model penelitian, didasarkan pada Augmented Dickey Fuller Test, yang perhitungannya menggunakan bantuan software E-Views 4.1. Pada tabel 1 dapat dilihat bahwa variabel FDR, ROA, IPI, SWBI dan NPF stasioner pada kondisi first difference. Kondisi ini ditunjukkan dengan angka probabilitas tiap variabel, semakin mendekati nol maka data dianggap stasioner. 
Tabel 1. Uji Stasioneritas (Intercept \& Trend)

\begin{tabular}{|c|c|c|c|c|c|c|}
\hline & \multicolumn{6}{|c|}{ Intercept \& Trend } \\
\hline & \multicolumn{3}{|c|}{ Level } & \multicolumn{3}{|c|}{$1^{\text {st }}$ Difference } \\
\hline & lag & t-stat & prob & lag & t-stat & prob \\
\hline FDR & 1 & -2.3298 & 0.4076 & 0 & -3.841 & 0.026 \\
\hline IPI & 0 & -5.4172 & 0.0005 & 1 & -6.730 & 0.000 \\
\hline ROA & 0 & -2.3167 & 0.4145 & 0 & -5.054 & 0.001 \\
\hline SWBI & 0 & -3.4533 & 0.0606 & 1 & -9.826 & 0.000 \\
\hline NPF & 0 & -1.7422 & 0.7107 & 0 & -4.842 & 0.002 \\
\hline
\end{tabular}

Sumber : Hasil Estimasi Eviews 4.1.

\section{Uji Multikolinieritas}

Langkah mendeteksi adanya masalah kolinieritas berganda maka digunakan alat uji Correlation Matrix yang ada dalam program E-Views 4.1. Matrik koefisien korelasi (Correlation Matrix) antara masing-masing variabel bebas dapat menunjukkan adanya kolinieritas berganda. Aturan yang biasa digunakan adalah menggunakan koefisien korelasi antara dua variabel bebas, bila lebih besar dari 0.8 atau 0.9 maka kolinieritas berganda merupakan masalah yang serius. Namun demikian korelasi pasangan ini tidak memberikan informasi lebih untuk hubungan yang lebih rumit antar tiga atau lebih variablel.

Tabel 2. Matrik koefisien korelasi (Correlation Matrix)

\begin{tabular}{lllll}
\hline & \multicolumn{1}{c}{ NPF } & \multicolumn{1}{c}{ ROA } & SWBI & IPI \\
\hline NPL & 1 & 0.187232 & 0.437159 & 0.295253 \\
ROA & 0.187232 & 1 & -0.05719 & 0.642106 \\
SWBI & 0.437159 & -0.05719 & 1 & -0.20405 \\
IPI & 0.295253 & 0.642106 & -0.20405 & 1 \\
\hline
\end{tabular}

Sumber : Hasil Estimasi Eviews 4.1.

Melalui penggunaan Correlation Matrix (table 2) maka terlihat bahwa tidak ada korelasi yang kuat antar variabel. Jadi data-data yang digunakan untuk penelitian ini bebas dari kolinieritas berganda.

42 


\section{Uji Heteroskedastisitas}

Pada penelitian ini, uji heterokedastisitas diterapkan dengan menggunkan White Heteroskedasticity Test yang tersedia di program E-Views 4.1. Uji ini diterapkan pada hasil regresi dengan menggunakan prosedur equations dan metode OLS untuk masing-masing persamaan. Hasil yang perlu diperhatikan dari uji ini adalah nilai $\mathrm{F}$ dan Obs*R-squared dengan Chi-squared tabel. Jika nilai Obs*R-squared lebih kecil daripada Chi-squared tabel, maka tidak ada heteroskedastisitas pada model. Dari Tabel 3 diketahui nilai Chi-square hitung adalah 11.99028 sedangkan nilai Chi-squared Tabel adalah 13,36 $(x=10 \%, d f=8)$. Sehingga dapat disimpulkan tidak terdapat masalah serius heteroskedastisitas karena nilai Chi-squared hitung lebih kecil daripada nilai tabel.

Tabel 3. White Heteroskedasticity Test

White Heteroskedasticity Test:

\begin{tabular}{llll}
\hline F-statistic & 1.693562 & Probability & 0.147523 \\
Obs*R-squared & 11.99028 & Probability & 0.151638
\end{tabular}

Sumber : Hasil Estimasi Eviews 4.1.

\section{Uji Autotokorelasi}

Untuk mendeteksi adanya otokorelasi dalam penelitian ini digunakan Serial Correlation LM Test yang tersedia pada program E-Views 4.1. Dengan melihat nilai F dan Obs*R-squared dapat diketahui ada atau tidaknya otokorelasi. Dimana jika nilai probabilitas dari Obs*R-squared melebihi tingkat keberartian maka Ho diterima dan berarti tidak ada masalah serius dengan otokorelasi., demikian sebaliknya.

Tabel 4. Breusch-Godfrey Serial Correlation LM Test

\begin{tabular}{lrll}
\hline \multicolumn{4}{c}{ Breusch-Godfrey Serial Correlation LM Test: } \\
\hline F-statistic & 0.771218 & Probability & 0.472024 \\
Obs*R-squared & 1.82738 & Probability & 0.401042
\end{tabular}

Sumber : Hasil Estimasi Eviews 4.1.

Dari hasil uji diatas diketahui nilai Chi-square hitungnya adalah 0.401042 , dengan menggunakan taraf signifikansi $10 \%(0,1)$ dapat disimpulkan nilai Chisquare Hitung lebih besar Taraf signifikansi. Maka tidak terdapat masalah serius autokorelasi 


\section{Analisis Hasil Regresi}

Pada akhirnya setelah melakukan penyembuhan data dan pengecekan terhadap pelanggaran asumsi maka dengan menggunakan OLS didapatkan hasil sebagai berikut :

Dependent Variable: D(FDR)

Method: Least Squares

Date: 05/29/06 Time: 16:42

Sample(adjusted): 2003:02 2005:12

Included observations: 35 after adjusting endpoints

\begin{tabular}{cclcc}
\hline \multicolumn{1}{c}{ Variable } & Coefficient & \multicolumn{1}{c}{ Std. Error } & t-Statistic & Prob. \\
\hline D(IPI) & -0.011420 & 0.064169 & -0.177968 & 0.8599 \\
D(NPF) & 3.777280 & 1.519735 & $2.485485 * *$ & 0.0187 \\
D(ROA) & 6.200059 & 2.312663 & $2.680918 * *$ & 0.0118 \\
D(SWBI) & 0.433747 & 0.257428 & 1.684925 & 0.1024 \\
C & -0.135292 & 0.504531 & -0.268154 & 0.7904 \\
\hline R-squared & 0.341256 & Mean dependent var & -0.080454 \\
Adjusted R-squared & 0.253423 & S.D. dependent var & 3.398782 \\
S.E. of regression & 2.936707 & Akaike info criterion & 5.124018 \\
Sum squared resid & 258.7274 & Schwarz criterion & 5.346211 \\
Log likelihood & -84.67032 & F-statistic & 3.885298 \\
Durbin-Watson stat & 1.679015 & Prob(F-statistic) & 0.011679 \\
\hline
\end{tabular}

Sumber : Hasil Estimasi Eviews. 4.1.

Dengan persamaan :

$F D R_{i, t}=$ const $+6.200 * R O A+3.777 * N P F+0.434 * S W B I-0.011 * I P I$

Nilai Prob (F-statistic) sebesar 0.01168 menunjukkan bahwa secara simultan variabel-variabel independen yang ditentukan dalam model signifikan mempengaruhi variabel dependen dengan taraf kepercayaan $5 \%$. Secara parsial nilai t-stat menunjukkan bahwa yang signifikan mempengaruhi variabel FDR adalah variabel NPF dan ROA dengan taraf kepercayaan $5 \%$. Sedangkan variabel IPI dan SWBI berpengaruh terhadap FDR namun tidak signifikan secara statistik.

Sementara itu nilai R-squared $\left(\mathrm{R}^{2}\right)$ sebesar 0.341 dapat diinterpretasikan bahwa $34.1 \%$ variasi tingkat pembiayaan perbankan syariah dapat dijelaskan oleh variabel Industrial Production Index (IPI), Non Performing Finances (NPF), Return on Asset (ROA), dan Sertifikat Wadi'ah Bank Indonesia (SWBI). Sedangkan sisanya diterangkan oleh variabel-variabel selain variabel tersebut. 


\section{PEMBAHASAN}

Berdasarkan hasil analisis dengan menggunakan metode OLS (Ordinary Least Square) diperoleh hasil estimasi sebagai berikut :

$$
F D R_{i, t}=\text { const }+6.200 * R O A+3.777 * N P F+0.434 * \text { SWBI }-0.011 * I P I
$$

Dari hasil estimasi diatas hanya menunjukkan satu variabel bebas yang memberikan sinyal selaras dan positif yaitu variabel ROA, sebesar 6.2. Sehingga menjelaskan bahwa kenaikan ROA sebesar $1 \%$ menyebabkan pembiayaan secara rata-rata naik sebesar $6.2 \%$. Kejadian tersebut dianggap wajar karena semakin besar keuntungan (return) yang diterima bank syariah dari asset yang disalurkan untuk pembiayaan menyebabkan semakin besar dana atau asset yang akan disalurkan untuk pembiayaan.

Hasil estimasi diatas lebih banyak mengemukakan fenomena-fenomena menarik yang terjadi dalam industri perbankan syariah di Indonesia yang berlawanan dengan asumsi yang terjadi pada perbankan konvensional. Untuk variabel NPF, peningkatan NPF sebesar $1 \%$ akan menyebabkan peningkatan pembiayaan sebesar 3.78\%, hubungan positif antara NPF dan pembiayaan (FDR) berbeda dengan praduga yang ada pada perbankan konvensional yaitu bahwa NPF berhubungan negative dengan pembiayaan (FDR). Hal ini secara lebih lanjut dapat dijelaskan bahwa NPF perbankan syariah lebih rendah dari perbankan konvensional. Lebih dari itu, bank syariah menyalurkan pembiayaan dengan prinsip bagi hasil kepada sektor riil secara berkeadilan, sehingga resiko ditanggung bersama antara pemilik dana, perbankan dan pengelola usaha. Penjelasan lain tentang rendahnya NPF adalah kesadaran nasabah bank syariah lebih tinggi atas tanggung jawabnya sebagai penerima pembiayaan serta menganggap pembiayaan yang diterimanya adalah titipan yang hukumnya wajib dikembalikan.

Kondisi serupa berlaku untuk SWBI, meskiun memiliki berhubungan yang positif dengan pembiayaan, namun sangat kecil. Kenaikan SWBI sebesar $1 \%$ menyebabkan pembiayaan secara rata-rata naik sebesar $0.43 \%$. Kondisi tersebut menjelaskan bahwa besarnya bonus SWBI yang ditawarkan Bank Indonesia pada bank syariah relatif kecil. Akan tetapi sebenarnya misi perbankan syariah adalah menyalurkan dana masyarakat kepada sektor riil, bukan disimpan pada Bank Indonesia untuk mendapatkan fasilitas SWBI, ada dana yang disimpan di BI hanya sesuai yang dipersyarat. Dan juga, pendapatan yang diterima bank syariah jika dana disalurkan pada jenis pembiayaan-pembiayaan bank syariah akan lebih tinggi daripada disimpan di BI untuk mendapatkan bonus SWBI, contohnya seperti pembiayaan murabahah. Sehingga bank syariah di Indonesia cenderung menyalurkan dananya pada sektor riil sesuai dengan misinya serta pada jenis pembiayaan mempunyai return lebih tinggi.

Demikian halnya dengan hasil estimasi terhadap dua variabel di atas juga ditunjukkan pada variabel IPI yang pada praduga awal diekspektasikan akan berhubungan positif dengan pembiayaan. Tetapi hasil estimasi menunjukkan bahwa terjadi hubungan negatif antara IPI dan pembiayaan, dimana kenaikan IPI 
sebesar $1 \%$ akan direspon dengan turunnya pembiayaan sebesar $0.01 \%$. hasil estimasi tersebut menjelaskan bahwa bank syariah kurang sensitif terhadap sinyal pasar atau kondisi sektor riil (dunia usaha dengan skala menengah keatas), karena mungkin selama ini (periode penelitian) perbankan syariah belum mempunyai nasabah sektor usaha dengan skala menengah atas yang mempunyai track-record yang meyakinkan. Pada kondisi yang nyata, kurangnya sarana dan prasarana atau infrstruktur bank syariah menjadi kendala bagi nasabah sektor riil khususnya industri skala menengah dan besar yang notabene memerlukan suatu pelayanan keuangan yang kompleks.

\section{SIMPULAN DAN REKOMENDASI \\ Simpulan}

Berdasarkan hasil analisis yang dilakukan maka diperoleh simpulan dan rekomendasi penelitian ini adalah :

1. Secara simultan variabel-variabel independen yang ditentukan dalam model mempunyai pengaruh yang signifikan terhadap variabel dependen dengan taraf kepercayaan $5 \%$. Secara parsial nilai t-stat menunjukkan bahwa yang signifikan mempengaruhi variabel FDR adalah variabel NPF dan ROA dengan taraf kepercayaan 5\%. Sedangkan variabel IPI dan SWBI berpengaruh terhadap FDR namun tidak signifikan secara statistik.

2. Fungsi intermediasi perbankan syariah yang diwakili oleh FDR sebagai variable dependen dan ROA, NPF, SWBI, serta IPI sebagai variable independen ternyata hanya variable ROA yang memiliki hubungan positip dengan variabel FDR. Kondisi ini dianggap wajar karena semakin besar keuntungan (return) yang diterima bank syariah dari asset yang disalurkan untuk pembiayaan menyebabkan makin besar dana atau aset yang akan disalurkan untuk pembiayaan

\section{Rekomendasi}

Perlunya mengoptimalkan kebijakan Office Chanelling yang telah disosialisasikan Bank Indonesia untuk menumbuhkan pangsa pasar bank syariah di Indonesia mengingat mayoritas penduduk Indonesia adalah muslim. Sehingga keberadaan produk pembiayaan perbankan syariah di Indonesia dapat lebih dikenal oleh masyarakat luas dan dalam jangka panjang fungsi intermediasi bank syariah dapat dirasakan oleh perekonomian nasional.

\section{DAFTAR PUSTAKA}

Abdullah, Piter dan Suseno. 2003. Fungsi Intermediasi Perbankan di Daerah: Pengukuran dan Identifikasi Faktor-faktor yang Mempengaruhi. Buletin Ekonomi Moneter Dan Perbankan (Vol. 5, No. 4, Maret). Bank Indonesia. Jakarta.

Afzal-ur-Rahman. 1990. Economics Doctrines of Islam (Vol. 1-3). $3^{\text {rd }}$ Edition. Islamic Publication Ltd.. Lahore. Pakistan. 
Al-Qur,anul karim dan Terjemahannya. Sari Agung. Jakarta.

Amin, Riawan. 2005. Bank Syariah sebagai Solusi yang Berkeadilan dan Brkerakyatan. 12/08/2003. www

Arief, Sritua. 1993. Metodologi Penelitian Ekonomi. Lembaga Penerbit FE-UI. Jakarta

Ascarya dan Diana Yumanita. 2005. Bank Syariah: Gambaran Umum. Seri Kebanksentralan No.14. PPSK Bank Indonesia. Jakarta.

Bank Indonesia. 1998. Undang-undang No.7 tahun 1992 tentang Perbankan sebagaimana telah diubah dengan Undang-undang No.10 tahun 1998. Direktorat Hukum Bank Indonesia. Jakarta.

Bank Indonesia. 2005. Statistik Perbankan Syariah Indonesia. Berbagai Edisi. Direktorat Perbankan Syariah Bank Indonesia. Jakarta.

Bank Indonesia. Online site: www.bi.go.id. diakses tanggal 8 Mei 2005

Bank Indonesia. Statistik Perbankan Indonesia. Beberapa Tahun Penerbitan. Bank Indonesia. Jakarta.

Enders, Walter. 1995. Applied Econometrics Time Series. Lowa State university. John Wiley \& Sons, Inc. Canada.

Gujarati, Damodar N. 2003. Basic Econometrics. $4^{\text {th }}$ Edition : McGraw-Hill.

Haddad, Muliaman D, dkk. 2004. Fungsi Intermediasi Bank Asing dalam Mendorong Pemulihan Sektor Riil di Indonesia. Direktorat Penelitian dan Pengaturan Perbankan - Bank Indonesia (Desember). Bank Indonesia. Jakarta.

Hubbard, Glenn. 2002. Money, the Financial System and the Economy. Irwin McGraw Hill.

Mintaroem, Karjadi. 2003. Analisis Pertumbuhan Produk Pembiayaan (Murabahah Dan Mudharabah) Pada Lembaga Perbankan Berbasis Syariah Di Indonesia, 19982003 (Faktor-faktor yang Mepengaruhi, Peluang dan Kendala yang Dihadapi). http://www.adln.lib.unair.ac.id. Surabaya.

Mishkin, Frederic S. 2004. The Economy of Money, Banking \& Financial Market. $7^{\text {th }}$ Edition. Columbia University. 
Muhammad. 2005. Metode Penelitian Ekonomi Islam: Pendekatan Kuantitatif. UPFE-UMY. Yogyakarta.

RAFA Consulting. 2004. Pelatihan Dasar Perbankan Syariah. RAFA Consulting dan Bank Indonesia. Jakarta.

Rose, Peter S. 2003. Money and Capital : Financial Institutions and Instrument in a Global Marketplace. Irwin McGraw Hill.

Ruhiat, Ahmad. 2005. Peran Perbankan Syariah dalam Mewujudkan Pemulihan Ekonomi Nasional. 03/10/2005. www. tazkiaonline.com.

Siamat, Dahlan. 2004. Manajemen Lembaga Keuangan. Lembaga Penerbit FE-UI. Edisi Ketiga.

Siddiqi, M. Nejatullah. 1996. Kemitraan Usaha dan Bagi Hasil dalam Hukum Islam. Dana Bhakti Prima Yasa. Yogyakarta.

Sudarsono, Heri. 2004. Bank dan Lembaga Keuangan Syariah. Ekonisia. Yogyakarta.

White, H. 1980. A Heteroscedasticity Consistent Covariance Matrix Estimator and a Direct Test of Heteroscedasticity. Econometrica. Vol.48, pp. 817-818. 